\title{
10 lat w stużbie muzyce kościelnej
}

Mija właśnie dziesięć lat, jak po I Kongresie Muzyki Liturgicznej, który odbywał się pod hasłem Musicam Sacram Promovere i miał miejsce w Krakowie, w 2004 roku rozpoczęło się ukazywanie naszego pisma. Przesłaniem tej publikacji było i jest jednoczenie środowiska muzyków kościelnych w Krakowie, a także w Polsce w tym właśnie dziele promocji i dbałości o muzykę kościelną.

Lata, w jakich ukazywało się nasze czasopismo, owocowały we wspaniałe dzieła odnowy i promocji muzyki kościelnej w Krakowie. W 2005 roku powstała w nowym kształcie Archidiecezjalna Szkoła Muzyczna I i II stopnia im. kard. Franciszka Macharskiego, Akademia Muzyczna i Uniwersytet Papieski Jana Pawła II wspólnie powołali do istnienia w 2008 roku Międzyuczelniany Instytut Muzyki Kościelnej w Krakowie, w którym kształcą się studenci na pierwszym w Polsce kierunku muzyka kościelna. W 2007 roku odbył się w Krakowie XXXIV Międzynarodowy Kongres Pueri Cantores pod hasłem Misericordias Domini in aeternum cantabo, na który przybyło blisko 3000 chórzystów z całego świata. W końcu także w 2011 roku powstała optymalna regulacja prawna dotycząca organistów Archidiecezji Krakowskiej. Temu wszystkiemu towarzyszyło naukowe spojrzenie, w którym to jednym z ważnych elementów było i jest pismo „Pro Musica Sacra”. Wszystkie te dzieła były promocją muzyki kościelnej, a zawdzięczamy je wielu wspaniałym ludziom zatroskanym o sprawę piękna i jakości muzyki w świątyniach.

Tym numerem naszego pisma chcemy podziękować wszystkim, którzy przez lata go tworzyli, w nim pisali, recenzowali i także stali się czytelnikami. Idea, nawet najwspanialsza, nigdy się nie uda, gdy nie jest tworzona w jedności. Dlatego jest to okazja, by powiedzieć: dziękuję!

W ten nurt wpisują się wszystkie rocznice, które świętujemy w obecnym roku. Jest on rokiem Witolda Lutosławskiego (z okazji 100. rocznicy jego urodzin - 25 stycznia). W tym roku przypadają też: 60. rocznica śmierci Ludomira Różyckiego, 130. rocznica śmierci i 200. rocznica urodzin Ryszarda Wagnera, 60. rocznica śmierci Sergiusza Prokofiewa, 180. rocznica urodzin Johannesa Brahmsa, 60. rocznica śmierci Grzegorza Fitelberga, 170. rocznica urodzin Edvarda Griega, 200. rocznica urodzin Giuseppe Verdiego, 175. rocznica uro- 
dzin George'a Bizeta, 120. rocznica śmierci Piotra Czajkowskiego, 180. rocznica urodzin Aleksandra Borodina, 80. rocznica urodzin Krzysztofa Pendereckiego, 150. rocznica urodzin Pietra Mascagniego. Tym wszystkim wielkim i wybitnym muzykom dedykujemy ten numer naszego pisma.

W obecnym numerze odnajdziemy wiele ciekawych artykułów, recenzji, polemik oraz informacji. Zachęcam do spojrzenia także i na ten numer z wielką życzliwością. Ufam, że każdy czytelnik znajdzie w nim coś dla siebie ciekawego.

ks. dr hab. Robert Tyrała Redaktor naczelny „Pro Musica Sacra”

Kraków, 15 czerwca 2013 roku 